\title{
Clonidine versus tramadol for post spinal anesthesia shivering
}

\author{
A meta-analysis of randomized controlled trials
}

Jinguo Wang, MD, PhD, Haixiao Zhao, MD, Yanhui Li, MD, PhD, Rui Wang, MD, Na Wang, MD, PhD.

$$
\begin{aligned}
& \text { ABSTRACT } \\
& \text { الأهداف : مقارنة عقار الكلونيدين بالترامادول في السيطرة على الارتعاش } \\
& \text { بعد تخدير العمود الفقري. }
\end{aligned}
$$

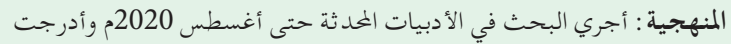

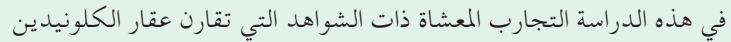

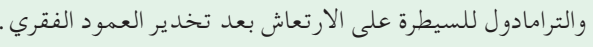

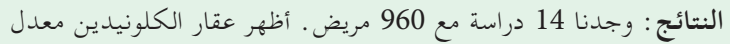

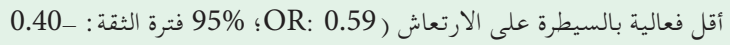

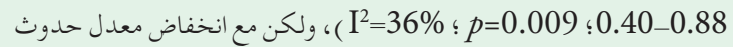

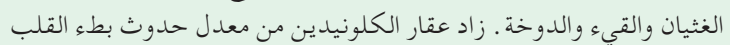

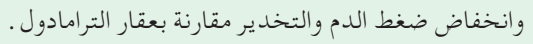

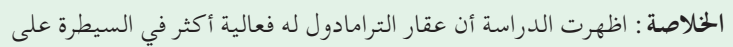

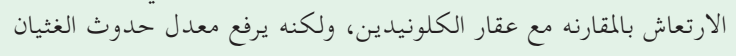

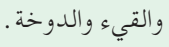

Objectives: To compare clonidine with tramadol for shivering control following spinal anesthesia.

Methods: The literature was searched updated to August 2020, and only randomized controlled trials comparing clonidine and tramadol for shivering control following spinal anesthesia were eligible for this study.

Results: Fourteen studies with 960 patients were identified. Clonidine demonstrated a lower effective rate of shivering control (OR: 0.59; 95\% CI: $\left.0.40-0.88 ; p=0.009 ; \mathrm{I}^{2}=36 \%\right)$, but with decreased occurrence of nausea, vomiting, and dizziness. Clonidine increased the occurrence of bradycardia, hypotension, and sedation compared to tramadol.

Conclusion: Tramadol is more effective for shivering control than clonidine, but with increased occurrence of nausea, vomiting, and dizziness.

\section{PROSPERO No: CRD42020207979}

Keywords: shivering, spinal anesthesia, clonidine, tramadol

Saudi Med J 2021; Vol. 42 (4): 363-362

doi: 10.15537/smj.2021.42.4.20200342

From the Department of Urology (WangJ, Zhao); from the Department of Anesthesiology (Li, Wang N), The First Hospital of Jilin University; and from the Engineering Department (Wang R), Jilin Business and Technology College, Changchun, China.

Received 7th October 2020. Accepted 26th January 2021.

Address correspondence and reprint request to: Dr. Na Wang, Department of Anesthesiology, The First Hospital of Jilin University. Changchun, China. E-mail: wang_na@jlu.edu.cn ORCID ID: https://orcid.org/0000-0002-8312-9787.

Shivering frequently occurs in the perioperative $S_{\text {period. }}{ }^{1}$ Various medications have been studied for shivering control, including dexmedetomidine, clonidine, pethidine, tramadol, magnesium sulphate, dexamethasone, and ketamine. ${ }^{2}$ Despite availability of numerous drugs for shivering control, no single drug has been found to be effective without any side effects.

In recent years, increasing randomized controlled trials (RCTs) comparing clonidine with tramadol for shivering control following spinal anesthesia have been conducted. Hence, we conducted this meta-analysis to compare clonidine with tramadol for shivering control following spinal anesthesia.

Methods. The recommendations of the PRISMA guidelines were followed in this meta-analysis. ${ }^{3}$ We 
searched Pubmed, Embase, Cochrane library, and Google Scholar, updated to August 2020 without language restrictions. All databases were searched using the following terms: "shivering," "clonidine," "tramadol," "hypothermia," "spinal anesthesia," "intrathecal injection," or "subarachnoid anesthesia." The references of all included articles were manually scanned for additional relevant publications.

Inclusion criteria were as follows: i) the study design is an RCT; ii) the participants were adult patients undergoing surgeries under spinal anesthesia; iii) the intervention of the study involved treating shivering following spinal anesthesia with intravenous clonidine or tramadol. The exclusion criteria were as follows: i) the study is not an RCT; ii) animal studies, meeting papers, editorials, correspondence, case reports or review papers; iii) and the intervention of the study includes clonidine or tramadol combined with other medications for shivering treatment.

The quality of the eligible RCTs were independently assessed by NW and HZ. Study quality was assessed with the Jadad score and the Cochrane risk of bias tool. ${ }^{4,5}$ Disagreement was solved by JW. The data from each eligible RCT was separately extracted by JW and YL. Disagreement was also settled by RW. The following data were obtained from each eligible article: number of patients, publication year, study interventions, effective parameters of shivering control (effective rate of shivering control and recurrence rate), and the related complications. The main outcome was the efficacy of shivering control, and the secondary outcome was the related complications (hypotension, bradycardia, sedation, nausea, vomiting, dizziness, dry mouth).

Statistical analysis. Review Manager 5.3 was used for statistical analysis. The efficacy of shivering control and the related complications were displayed by the odds ratio (OR) with 95\% confidence intervals (CI). Heterogeneity was estimated by the value of $\mathrm{I}^{2}$. If $\mathrm{I}^{2}$ was less than $50 \%$, data were analyzed utilizing the fixedeffect model, or the random-effects model. $P<0.05$ was statistically significant.

Results. Initially, we found 476 studies. After assessment, 22 full texts were included; however, 8 articles were excluded because they involved children or animals, or were non-RCTs or correspondences.

Disclosure. Authors have no conflict of interests, and the work was not supported or funded by any drug company.
Thus, 14 RCTs involving 960 patients were eligible for the present study. ${ }^{6-19}$ (Figure 1) Table 1 displays the characteristics of the identified RCTs in details and shows that all included studies in this meta-analysis had moderate to high quality. A risk-of-bias overview is shown in Figure 2.

As shown in Figure 3A, 12 studies including 860 participants recorded the effective rate of shivering control, and clonidine was less effective than tramadol (OR: 0.59; 95\% CI: 0.40-0.88; $p=0.009 ; \mathrm{I}^{2}=36 \%$ ). The difference in shivering recurrence rate was not statistically significant between clonidine and tramadol (OR: $0.82 ; 95 \%$ CI: 0.52-1.31; $p=0.41 ; \mathrm{I}^{2}=36 \%$ ). (Figure 3B)

The most common treatment-related complications were evaluated. Clonidine had higher incidences of hypotension (OR: 5.97; 95\% CI: 2.76-12.91;

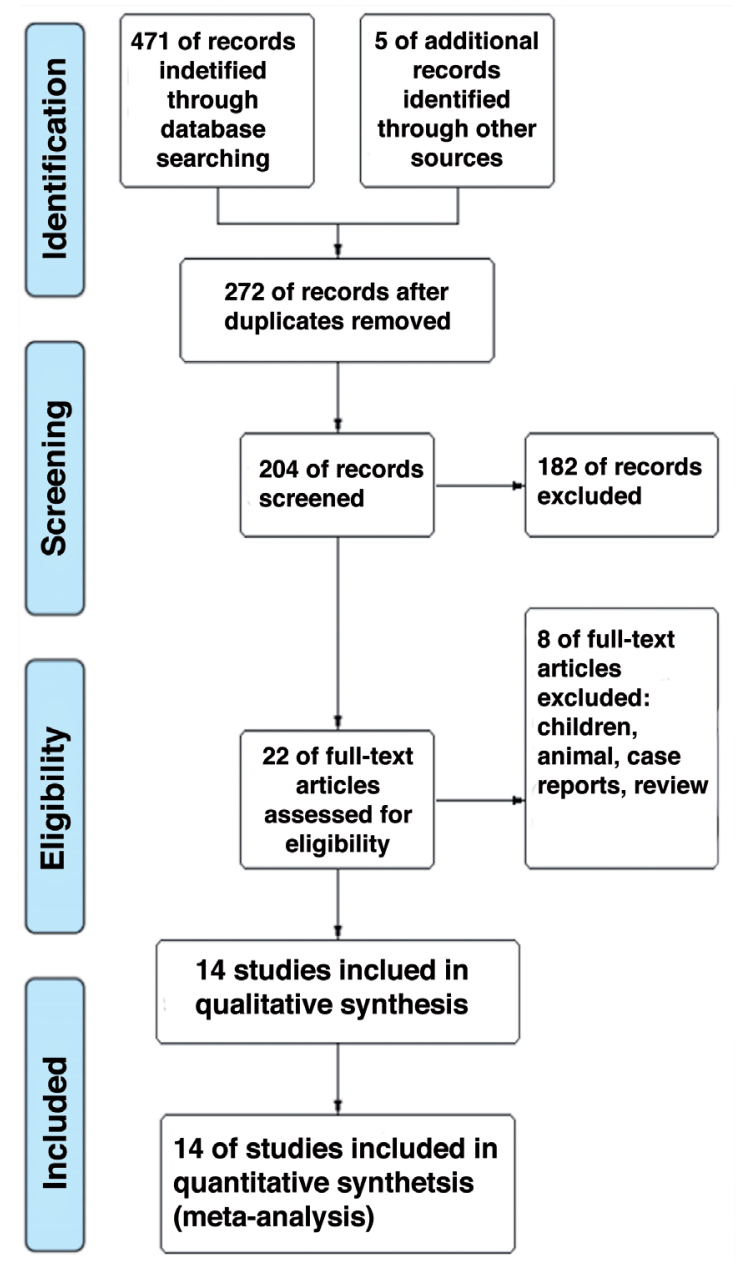

Figure 1 - Flow chart of selected randomized controlled trials. 
Table 1 - Characteristics of the included trials.

\begin{tabular}{|c|c|c|c|c|c|c|c|c|}
\hline $\begin{array}{l}\text { Author/ } \\
\text { date }\end{array}$ & Dosage & $\begin{array}{l}\text { Study } \\
\text { type }\end{array}$ & $\begin{array}{l}\text { Jadad } \\
\text { score }\end{array}$ & $\begin{array}{l}\text { Sample } \\
\text { size } \\
\mathrm{D} / \mathrm{T}\end{array}$ & $\begin{array}{l}\text { Patient characteristics; } \\
\text { surgical setting }\end{array}$ & $\begin{array}{l}\text { Type of anesthesia; } \\
\text { drug for anesthesia }\end{array}$ & $\begin{array}{l}\text { Degrees of } \\
\text { shivering }\end{array}$ & $\begin{array}{c}\text { Outcomes } \\
\text { measures }\end{array}$ \\
\hline $\begin{array}{l}\text { Shukla et al } \\
2011\end{array}$ & $\begin{array}{l}\text { Clonidine } \\
0.5 \mu \mathrm{g} / \mathrm{kg} ; \\
\text { tramadol } \\
0.5 \mathrm{mg} / \mathrm{kg}\end{array}$ & RCT & 4 & $40 / 40$ & $\begin{array}{l}18-40 \mathrm{yr}, \text { ASA: I; } \\
\text { Elective abdominal, } \\
\text { orthopaedic and } \\
\text { gynaecological surgeries }\end{array}$ & $\begin{array}{l}\text { Spinal anesthesia; } \\
0.5 \% \text { bupivacaine } \\
10-15 \mathrm{mg}\end{array}$ & Grades 3 or 4 & $\begin{array}{c}1,2,3,4 \\
5,6,7,8\end{array}$ \\
\hline $\begin{array}{l}\text { Vyas et al } \\
2018\end{array}$ & $\begin{array}{l}\text { Clonidine } \\
1 \mu \mathrm{g} / \mathrm{kg} \\
\text { tramadol } \\
1 \mathrm{mg} / \mathrm{kg}\end{array}$ & RCT & 4 & $30 / 30$ & $\begin{array}{l}\text { 18-65 yr, ASA: I-II; } \\
\text { Elective lower abdominal } \\
\text { and lower limb surgeries }\end{array}$ & $\begin{array}{l}\text { Spinal anesthesia; } \\
0.5 \% \text { heavy } \\
\text { bupivacaine }\end{array}$ & $\begin{array}{l}\text { Grades } 1-4 \\
\text { for at least } 2 \\
\text { minutes }\end{array}$ & $\begin{array}{c}1,2,3,4 \\
5,6,7,8\end{array}$ \\
\hline $\begin{array}{l}\text { Venkatraman } \\
\text { et } \mathrm{al}^{8} \\
2018\end{array}$ & $\begin{array}{l}\text { Clonidine } \\
1 \mu \mathrm{g} / \mathrm{kg} \\
\text { tramadol } \\
1 \mathrm{mg} / \mathrm{kg}\end{array}$ & RCT & 5 & $30 / 30$ & $\begin{array}{l}\text { 18-70 yr, ASA: I-II; } \\
\text { Lower abdominal, lower } \\
\text { limb, orthopaedic and } \\
\text { plastic surgeries }\end{array}$ & $\begin{array}{l}\text { Spinal anesthesia; } \\
\text { No mention }\end{array}$ & $\begin{array}{l}\text { Grades } 2,3 \\
\quad \text { or } 4\end{array}$ & $\begin{array}{l}1,2,3,4 \\
5,6\end{array}$ \\
\hline $\begin{array}{l}\text { Bansal \& Jain }{ }^{9} \\
2011\end{array}$ & $\begin{array}{l}\text { Clonidine } 150 \mu \mathrm{g} \\
\text { tramadol } \\
50 \mathrm{mg}\end{array}$ & RCT & 4 & $30 / 30$ & $\begin{array}{l}\text { 18-65 yr, ASA: I-III; } \\
\text { Urological, inguinal, and } \\
\text { lower limb surgeries }\end{array}$ & $\begin{array}{l}\text { Spinal anesthesia; } \\
0.5 \% \text { heavy } \\
\text { bupivacaine } \\
3.2-3.5 \mathrm{~mL}\end{array}$ & Grade 2 or 3 & $\begin{array}{c}1,2,3 \\
5,6\end{array}$ \\
\hline $\begin{array}{l}\text { Verma \& } \\
\text { Kumar }^{10} \\
2016\end{array}$ & $\begin{array}{l}\text { Clonidine } \\
0.5 \mu \mathrm{kg} / \mathrm{kg} \\
\text { tramadol } \\
1.5 \mathrm{mg} / \mathrm{kg} \\
\text { (maximum } \\
100 \mathrm{mg})\end{array}$ & RCT & 3 & $30 / 30$ & $\begin{array}{l}\text { 18-45 yr, ASA: I-II; } \\
\text { Elective abdominal, } \\
\text { gynecological and } \\
\text { orthopedic surgeries }\end{array}$ & $\begin{array}{l}\text { Spinal anesthesia; } \\
0.5 \% \text { heavy } \\
\text { bupivacaine } \\
15 \mathrm{mg}\end{array}$ & $\begin{array}{l}\text { Grade } 2,3 \text { or } \\
\text { grade } 4\end{array}$ & $\begin{array}{c}1,2,3,4 \\
5,6\end{array}$ \\
\hline $\begin{array}{l}\text { Attal et } \mathrm{al}^{11} \\
2015\end{array}$ & $\begin{array}{l}\text { Clonidine } \\
50 \mu \mathrm{g} \\
\text { tramadol } \\
50 \mathrm{mg}\end{array}$ & RCT & 3 & $30 / 30$ & $\begin{array}{l}\text { 18-40 yr, ASA: I-II; } \\
\text { Elective lower abdominal } \\
\text { and lower limb surgeries }\end{array}$ & $\begin{array}{l}\text { Spinal anesthesia; } \\
0.5 \% \text { heavy } \\
\text { bupivacaine } \\
3.5 \mathrm{~mL}\end{array}$ & $\begin{array}{l}\text { Grade } 3 \text { or } 4 \\
\text { for at least } 2 \\
\text { minutes }\end{array}$ & $\begin{array}{l}1,2,3,4 \\
\quad 5,6,8\end{array}$ \\
\hline $\begin{array}{l}\text { Reddy \& } \\
\text { Chiruvella }^{12} \\
2011\end{array}$ & $\begin{array}{l}\text { Clonidine } \\
50 \mu \mathrm{IV} \\
\text { tramadol } \\
50 \mathrm{mg} \text { IV }\end{array}$ & RCT & 4 & $45 / 45$ & $\begin{array}{l}\text { 18-35 yr, ASA: I-II; } \\
\text { Elective or emergency } \\
\text { caesarean section }\end{array}$ & $\begin{array}{l}\text { Spinal anesthesia; } \\
0.5 \% \text { heavy } \\
\text { bupivacaine } \\
10 \mathrm{mg}\end{array}$ & $\begin{array}{l}\text { Grade } 3 \text { or } 4 \\
\text { for at least } 3 \\
\text { minutes }\end{array}$ & $\begin{array}{c}1,2,4,5 \\
\quad 6,8\end{array}$ \\
\hline $\begin{array}{l}\text { Kulshrestha }{ }^{13} \\
2014\end{array}$ & $\begin{array}{l}\text { Clonidine } \\
50 \mu \mathrm{g} \mathrm{IV} \\
\text { tramadol } \\
50 \mathrm{mg} \mathrm{IV}\end{array}$ & RCT & 4 & $45 / 45$ & $\begin{array}{l}\text { 18-35 yr, ASA: I-II; } \\
\text { Elective Elective Lower } \\
\text { Segment Caesarean } \\
\text { Section }\end{array}$ & $\begin{array}{l}\text { Spinal anesthesia; } \\
0.5 \% \text { bupivacaine } \\
12 \mathrm{mg}\end{array}$ & $\begin{array}{l}\text { Grade } 3 \text { or } 4 \\
\text { for at least } 3 \\
\text { minutes }\end{array}$ & $\begin{array}{c}1,2,3,4 \\
5,6,7,8\end{array}$ \\
\hline $\begin{array}{l}\text { Aravind et } \mathrm{al}^{14} \\
2014\end{array}$ & $\begin{array}{l}\text { Clonidine } \\
1 \mu \mathrm{g} / \mathrm{kg} ; \\
\text { tramadol } \\
1 \mathrm{mg} / \mathrm{kg} \mathrm{IV}\end{array}$ & RCT & 4 & $40 / 40$ & $\begin{array}{l}\text { 18-40 yr, ASA: I-II; } \\
\text { Various surgeries }\end{array}$ & $\begin{array}{l}\text { Spinal anesthesia; } \\
0.5 \% \text { heavy } \\
\text { bupivacaine }\end{array}$ & $\begin{array}{l}\text { Grade } 2,3 \text { or } \\
\text { grade } 4 \\
\text { for at least } 2 \\
\text { minutes. }\end{array}$ & $1,2,5$ \\
\hline $\begin{array}{l}\text { Longani et al }{ }^{15} \\
2017\end{array}$ & $\begin{array}{l}\text { Clonidine } \\
150 \mu \mathrm{g} \text { IV; } \\
\text { tramadol } \\
50 \mathrm{mg} \mathrm{IV}\end{array}$ & RCT & 3 & $40 / 40$ & $\begin{array}{c}\text { 25-50 yr, ASA: I-II; } \\
\text { Elective lower stomach } \\
\text { and lower appendage } \\
\text { surgeries, }\end{array}$ & $\begin{array}{l}\text { Spinal anesthesia; } \\
0.5 \% \text { bupivacaine } \\
14 \mathrm{mg}\end{array}$ & $\begin{array}{l}\text { Grade } 3 \text { or } 4 \\
\text { for at least } 2 \\
\text { minutes }\end{array}$ & $\begin{array}{c}1,2,3,4 \\
5,8\end{array}$ \\
\hline $\begin{array}{l}\text { Jois et al }{ }^{16} \\
2016\end{array}$ & $\begin{array}{l}\text { Clonidine } \\
0.5 \mu \mathrm{g} / \mathrm{kg} \mathrm{IV;} \\
\text { tramadol } \\
0.5 \mathrm{mg} / \mathrm{kg} \mathrm{IV}\end{array}$ & RCT & 4 & $40 / 40$ & $\begin{array}{l}25-50 \mathrm{yr} \text {, ASA: I-II; } \\
\text { Lower abdominal and } \\
\text { lower limb surgeries }\end{array}$ & $\begin{array}{c}\text { Spinal anesthesia } \\
0.5 \% \text { heavy } \\
\text { bupivacaine } 2-4 \mathrm{~mL}\end{array}$ & Grade 3 or 4 & $\begin{array}{c}1,2,3,4 \\
5,6,7,8\end{array}$ \\
\hline $\begin{array}{l}\text { Singh et al }{ }^{17} \\
2016\end{array}$ & $\begin{array}{l}\text { Clonidine } \\
0.5 \mu \mathrm{g} / \mathrm{kg} \mathrm{IV} \\
\text { tramadol } \\
0.5 \mathrm{mg} / \mathrm{kg} \mathrm{IV}\end{array}$ & RCT & 4 & $30 / 30$ & $\begin{array}{c}20-50 \mathrm{yr}, \text { ASA: I-II; } \\
\text { elective lower abdominal, } \\
\text { lower limb orthopaedic } \\
\text { and gynaecological } \\
\text { surgeries }\end{array}$ & $\begin{array}{c}\text { Spinal anesthesia } \\
0.5 \% \text { heavy } \\
\text { bupivacaine } 15 \mathrm{mg}\end{array}$ & Grade 3 or 4 & $\begin{array}{c}1,2,3,4 \\
5,6,8\end{array}$ \\
\hline $\begin{array}{l}\text { Ali \& } \\
\text { Debata }^{18} \\
2017\end{array}$ & $\begin{array}{l}\text { Clonidine } \\
50 \mu \mathrm{g} \text { IV; } \\
\text { tramadol } \\
50 \mathrm{mg} \mathrm{IV}\end{array}$ & RCT & 3 & $30 / 30$ & $\begin{array}{l}\text { 18-60 yr, ASA: I-II; } \\
\text { elective lower abdominal } \\
\text { and lower limb surgery } \\
\text { under spinal anesthesia }\end{array}$ & $\begin{array}{l}\text { Spinal anesthesia } \\
0.5 \% \text { heavy } \\
\text { bupivacaine }\end{array}$ & $\begin{array}{l}\text { Grade } 1,2 \\
\quad \text { or } 3\end{array}$ & 2,5 \\
\hline $\begin{array}{l}\text { Kumar et } \mathrm{a}^{19} \\
2016\end{array}$ & $\begin{array}{l}\text { Clonidine } \\
0.6 \mu \mathrm{g} / \mathrm{kg} \mathrm{IV} \\
\text { tramadol } \\
1.0 \mathrm{mg} / \mathrm{kg} \mathrm{IV}\end{array}$ & RCT & 3 & $20 / 20$ & $\begin{array}{l}\text { 18-60 yr, ASA: I-II; } \\
\text { elective lower abdominal } \\
\text { surgeries,orthopaedics } \\
\text { lower limb surgeries and } \\
\text { plastic surgeries. }\end{array}$ & $\begin{array}{c}\text { Spinal anesthesia } \\
0.5 \% \text { heavy } \\
\text { bupivacaine } 15 \mathrm{mg}\end{array}$ & Grades 3 or 4 & 3 \\
\hline
\end{tabular}

RCT: randomized controlled trial, ASA: American Society of Anesthesiologists, YR: year, IR: intravenous, Outcome measures: 1) Effective rate of shivering control, 2) Time to cease shivering, 3) Recurrent rate of shivering, 4) The incidence of bradycardia and hypotension, 5) The incidence of nausea and vomiting, 6) The incidence of sedation, 7) The incidence of dizziness, 8) The incidence of dry mouth 
Clonidine versus tramadol for shivering ... Wang et al

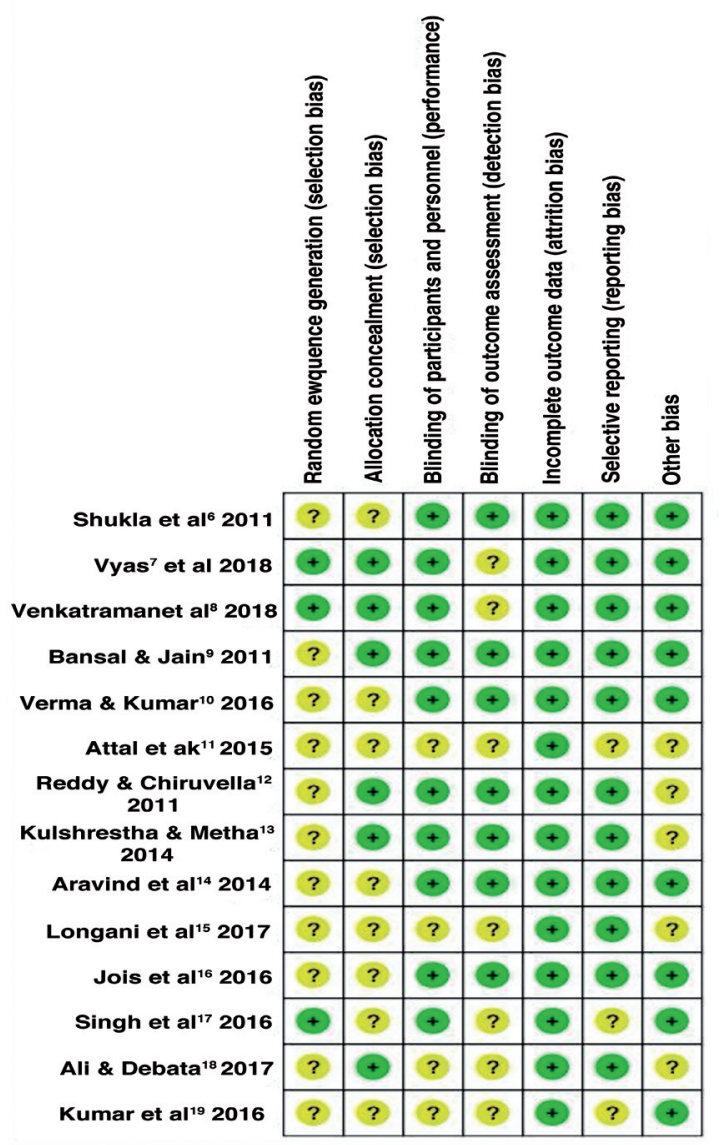

Figure 2 - Risk of bias evaluation.

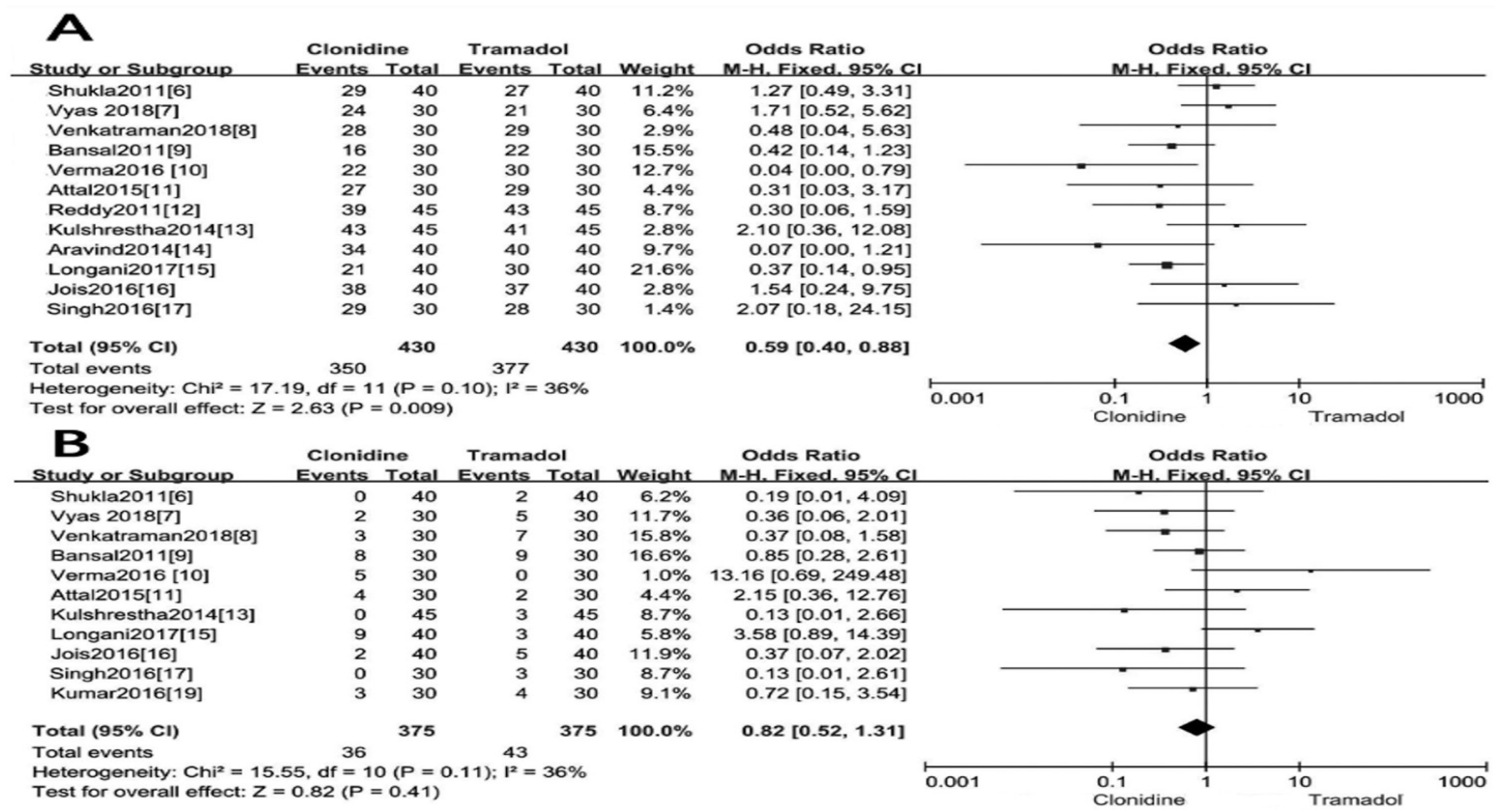

Figure 3 - A) Forest plot for effective rate of shivering control, B) and recurrent rate of shivering. 


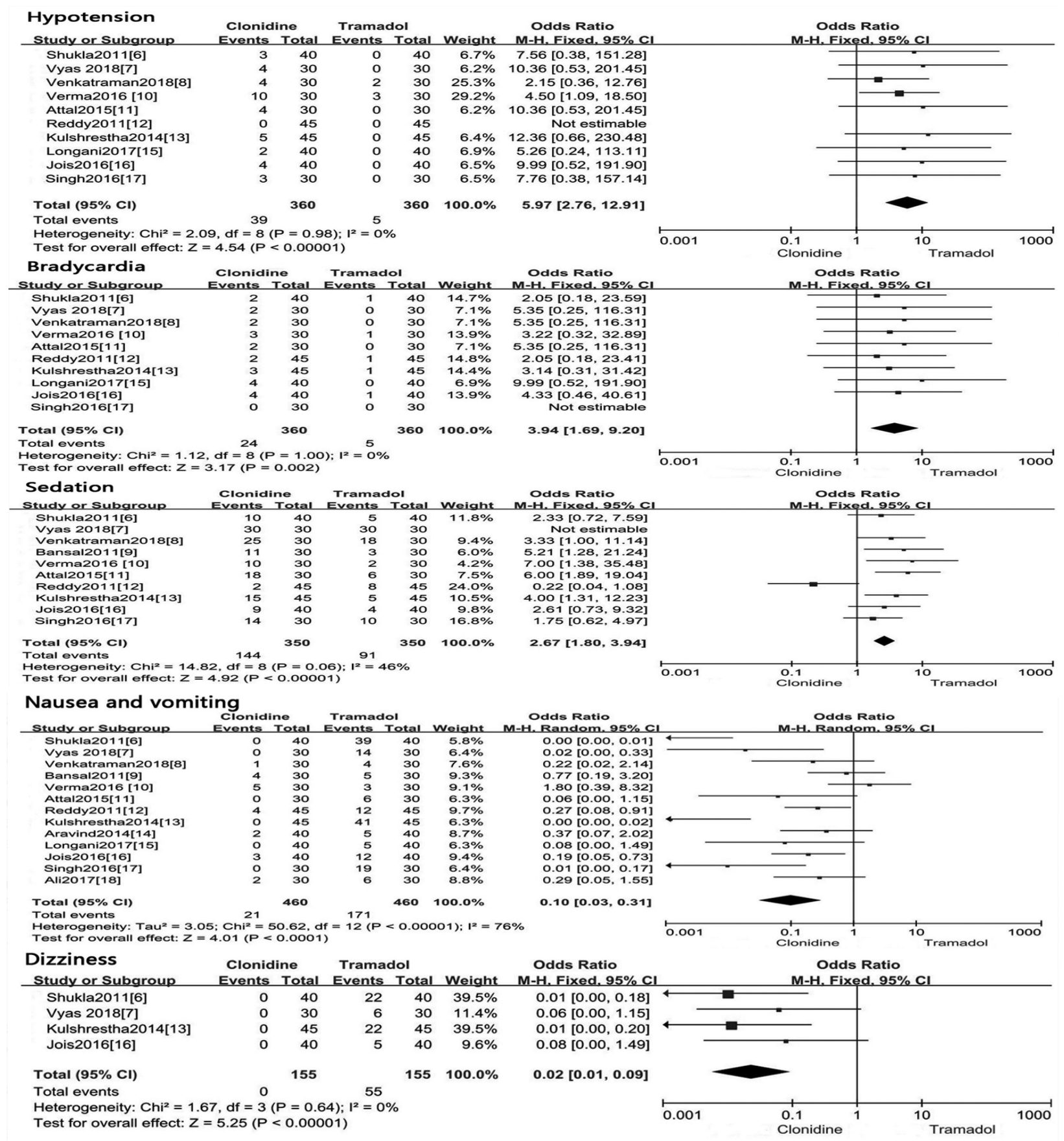

\section{Dry mouth}

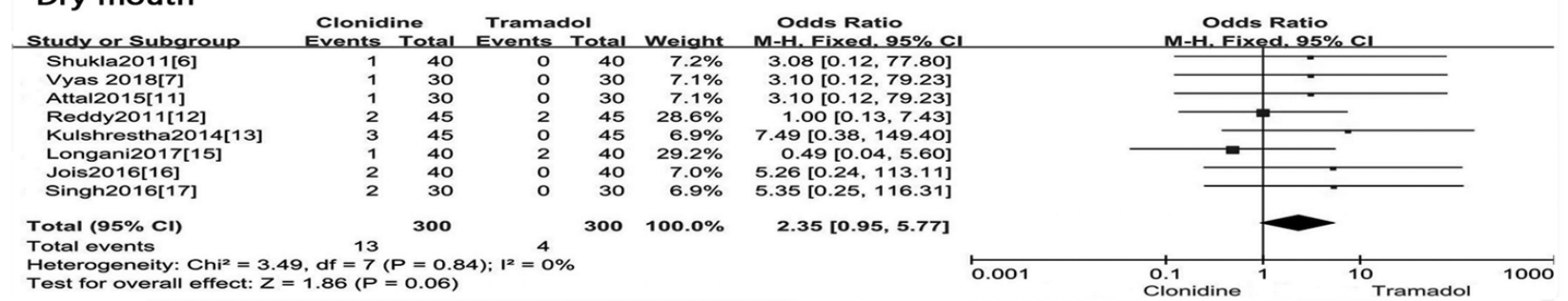

Figure 4 - Forest plot for related complications (hypotension, bradycardia, sedation, nausea, vomiting, dizziness, dry mouth). 
$p<0.00001 ; \mathrm{I}^{2}=0 \%$ ), bradycardia (OR: 3.94; 95\% CI: $\left.1.69-9.20 ; p=0.002 ; \mathrm{I}^{2}=0 \%\right)$, and sedation (OR: 2.67; 95\% CI: $1.80-3.94 ; p<0.00001 ; \mathrm{I}^{2}=46 \%$ ), and lower incidence of dizziness (OR: 0.02; 95\% CI: 0.01-0.09; $p<0.00001 ; \mathrm{I}^{2}=0 \%$ ) compared with tramadol. (Figure 4)

Compared with tramadol, clonidine had a lower incidence of nausea and vomiting (OR 0.10; 95\% CI: 0.03-0.31; $p<0.0001 ; \mathrm{I}^{2}=76 \%$ ) (Figure 4). Sensitivity analysis was performed by taking out every included RCT sequentially. The result was confirmed, and no source of heterogeneity was identified.

The difference in the incidence of dry mouth was not statistically significant between clonidine and tramadol (OR: 2.35; 95\% CI: 0.95-5.77; $p=0.06$; $\mathrm{I}^{2}=0 \%$ ) (Figure 4).

The funnel plot of the effective rate of shivering control was symmetrical, so there were no potential publication biases.

Discussion. The present meta-analysis indicates that tramadol is more effective than clonidine for shivering control following spinal anesthesia. However, the difference is not significant in the shivering recurrence rate between clonidine and tramadol. In terms of complications, tramadol use resulted in higher incidences of nausea, vomiting, and dizziness, while clonidine increased the probability of bradycardia, hypotension, and sedation.

Nausea, vomiting, and dizziness are very distressing for patients and may lead to serious consequences. ${ }^{20}$ According to the included RCTs, bradycardia and hypotension could be promptly treated by intravenous drugs. If surgeries are performed under spinal anesthesia, sedation caused by clonidine is beneficial for the patients. In addition, no patients were over sedated in the identified studies.

Clonidine has a high lipid solubility; therefore, it can promptly cross the blood-brain barrier. ${ }^{21}$ Hence, clonidine can activate $\alpha 2$ receptors in the central nervous system to reduce the central thermosensitivity by suppressing the neuronal conductance, consequently reducing the thermoregulatory threshold for shivering. ${ }^{21}$ The antishivering mechanism of tramadol possibly results from its opioid or serotonergic and noradrenergic function. ${ }^{22}$

Although the search strategy was designed to be as thorough as possible to identify eligible RCTs, the included RCTs were limited. Tramadol can significantly increase the effective rate of shivering treatment, but in terms of the complications, there is not enough clinical evidence to determine which of the 2 , clonidine or tramadol, is better for shivering treatment after spinal anesthesia. Thus, further high-quality evidence from a large sample is needed.

In conclusion, tramadol is more effective than clonidine for shivering treatment, but with increased incidences of nausea, vomiting, and dizziness.

Acknowledgment. The authors gratefully acknowledge Editage (www.editage.cn) for English language editing.

\section{References}

1. Wang J, Wang Z, Liu J, Wang N. Intravenous dexmedetomidine versus tramadol for treatment of shivering after spinal anesthesia: a meta-analysis of randomized controlled trials. BMC Anesthesiol 2020; 20: 104.

2. Choi KE, Park B, Moheet AM, Rosen A, Lahiri S, Rosengart A. Systematic quality assessment of published antishivering protocols. Anesth Analg 2017; 124: 1539-1546.

3. Liberati A, Altman DG, Tetzlaff J, Mulrow C, Gøtzsche PC, Ioannidis JPA, et al. The PRISMA statement for reporting systematic reviews and meta-analyses of studies that evaluate healthcare interventions: explanation and elaboration. BMJ 2009; 339: b2700.

4. Jadad AR, Moore RA, Carroll D, Jenkinson C, Reynolds DJ, Gavaghan DJ, et al. Assessing the quality of reports on randomized clinical trials: is blinding necessary? Controlled Clinical Trials 1996; 17: 1-12.

5. Higgins JP, Altman DG, Gøtzsche PC, Jüni P, Moher D, Oxman AD, et al. The Cochrane Collaboration. BMJ 2011; 343: d5928.

6. Shukla U, Malhotra K, Prabhakar T. A comparative study of the effect of clonidine and tramadol on post spinal anaesthesia shivering. Indian J Anaesth 2011; 55: 242-246.

7. Vyas V, Gupta R, Dubey P. Comparative efficacy and safety of intravenous clonidine and tramadol for control of postspinal anesthesia shivering. Anesth Essays Res 2018; 12: 663-668.

8. Venkatraman R, Karthik K, Pushparani A, Mahalakshmi A. A prospective, randomized, double-blinded control study on comparison of tramadol, clonidine and dexmedetomidine for post spinal anesthesia shivering. Revista Brasileira de Anestesiologia 2018; 68: 42-48.

9. Bansal P, Jain G. Control of shivering with clonidine, butorphanol, and tramadol under spinal anesthesia: a comparative study. Local Reg Anesth 2011; 4: 29-34.

10. Verma DNK, Kumar DM. Comparison of clonidine, dexmedetomidine and tramadol for control of post spinal shivering: A randomized double blind clinical study. Int J Life Sci Scienti Res 2016; 2: 658-664.

11. Attal P, Chhaya A, Singh T, Upadhayaya RM. Comparison of clonidine and tramadol for the control of shivering under spinal anaesthesia. Int J Biomed 2015; 6: 25-31.

12. Reddy VS, Chiruvella S. Clonidine versus tramadol for post spinal shivering during caesarean section: A randomized double blind clinical study. J Obstet Anaesth Crit Care 2011; 1: 26-29.

13. Kulshrestha S, Mehta RK. Efficacy of intravenous clonidine \& tramadol on post spinal anaesthesia shivering in elective lower segment caesarean section: a randomized comparative study. PJSR 2014; 7: 7-11. 
14. Aravind V, Dhakshinamoorthy M, Dhanasekaran C. A comparative study of clonidine and tramadol for the control of post spinal anaesthesia shivering. Int J Modn Res Revs 2014; 2: 379-384.

15. Longani S, Srivastava A, Bogra J, Agarwal A. A comparative study for control of shivering with clonidine, butorphanol and tramadol in patients undergoing neuraxial blockade. J Med Sci Clin Res 2017; 5: 29134-29139.

16. Jois DSM, Rao S, Krishna LS, Babu AS. A Prospective, randomized, double blinded, comparative study of clonidine and tramadol for control of shivering under spinal anesthesia. $J$ Med Sci Clin Res 2016; 4: 11913-11921.

17. Singh A, Gupta KK, Solanki SL, Kumar M. A prospective randomized double blind comparative study of clonidine, dexmedtomidine and tramadol for treatment of shivering under spinal anaesthesia. Indian J Public Health 2016; 7: 114-119.
18. Ali SM, Debata PC. Comparative effectiveness of tramadol, clonidine \& butorphanol for the control of shivering in patients undergoing neuraxial blockade. Int J Med Res Prof 2017; 3: 124-129.

19. Kumar YD, Kumar TR, Sasi RK. Prachi P. A clinical comparative study of dexmedetomidine, clonidine and tramadol in post spinal shivering in lower limb and lower abdominal surgeries. $J$ Med Dent Sci 2016; 15: 50-54.

20. Weibel S, Rücker G, Eberhart LH, Pace NL, Hartl HM, Jordan $\mathrm{OL}$, et al. Drugs for preventing postoperative nausea and vomiting in adults after general anaesthesia: a network metaanalysis. Cochrane Database Syst Rev 2020; 10: CD012859.

21. Sanchez Munoz MC, De Kock M, Forget P. What is the place of clonidine in anesthesia? Systematic review and meta-analyses of randomized controlled trials. J Clin Anesth 2017; 38: 140-153.

22. Barakat A. Revisiting tramadol: A multi-modal agent for pain management. CNS Drugs 2019; 33: 481-501. 